\title{
Biodiesel Production Potential from Native Tehran Oil Crops Using GIS
}

\author{
Ahmad Hajinezhad \\ Faculty of Science and Technology \\ Modern University of Tehran \\ Iran \\ hajinezhad@ut.ac.ir
}

\author{
Saeed Rahebi \\ Faculty of Science and Technology \\ Modern University of Tehran \\ Iran \\ shafabakhsh@semnan.ac.ir
}

\author{
Sepide Abedi \\ Faculty of Science and Technology \\ Modern University of Tehran \\ Iran \\ ahadad@semnan.ac.ir
}

\begin{abstract}
One of the main factors in the field of alternative fuel economy is the primary raw materials. Importing raw materials and preparation conditions for cultivation of non-native species require high expenditures. Using native species can reduce the production cost. Therefore in this paper, for the first time a comprehensive study of indigenous Tehran oil plants is presented. Three indigenous non-edible species, rapeseed, cotton and barley were selected due to their feasibility of producing biodiesel. The purpose of this study is to propel relevant policies in the country towards greater use of domestic raw materials and known potentials. The potential for biodiesel production from plant sources, in this region was studied using GIS software. The present paper describes the zoning map and identifies the potential map of producing biodiesel from indigenous plant sources in Tehran province. According to the map, concentration of biodiesel production is in the central and western cities of province. This map shows that 116806.8665 hectares with the greatest potential to produce biodiesel. Also we calculated the potential of biodiesel production from introduced species, considering the yield per hectare and their oil content. The results show that the potential of biodiesel production for the three species of rapeseed, cotton and barley are respectively 98117.77, 58403.43, 83516.91 tons in Tehran province. Non-edible rapeseed having the highest production potential has been introduced as a superior indigenous species for the future investments in biodiesel production in Tehran province.
\end{abstract}

Keywords-biodiesel; indigenous oil plants; GIS; biodiesel production potential

\section{INTRODUCTION}

Endemic plant species, as a factor strategy to ensure environmental sustainability in agricultural programs, provide genes which are resistant to unfavorable environmental factors, disease and pest, are one of the most important national and natural assets. Biodiesel (biodiesel technically is termed as Fatty Acid Methyl Ester) is a clean diesel fuel from renewable natural resources such as vegetable oils and animal fats. Oil plants are one of the biodiesel production sources. This study is based on the evaluation of producing biodiesel as an alternative fuel from endemic oil plants. Because the performance of biodiesel in compression ignition engines is the same as diesel fuel, therefore, its use doesn't need engine modifications.
Using biodiesel in a conventional diesel engine can reduce unburned hydrocarbons, carbon monoxide and particulate matter. Also, due to its oxygen and complete combustion to $\mathrm{CO}_{2}$, the proportions of carbon are reduced in the suspended particles. Sulfate present in the oil sector are absent due to the absence of sulfur in biodiesel. Thus, despite similar physical and chemical properties of biodiesel with conventional diesel, the exhaust output of the bio fuel has an advantage over conventional gasoline fuel. When the production of biodiesel started the process of transesterfication (what we do to make biodiesel) was used to separate glycerine from oil. Glycerine was widely used in the cosmetic, food and explosive industries [1]. As petroleum fuels were plentiful and cheap, the main interest was on designing increasingly more sophisticated fuel injection systems [2]. Over the years, this meant that vehicles evolved to run thinner fossil diesels rather than thicker vegetable oils. Once the price of crude oil increased though, there was an incentive for research on alternative fuels. It was already pretty much accepted that unmodified vegetable oil was not suitable for modern injection systems. The transesterfication process was pretty much old science and was used to reduce the viscosity of the oil; producing biodiesel [3, 4], so commercial process to turn waste cooking oil into biodiesel was developed [5]. In the 2000's when crude prices started rising, government subsidy of biofuel industries became common. This has given the industry the economic security needed to invest in biofuels. In Iran, researches around producing biofuels are performed since 1996, especially in case of biodiesel from different resources [6] as using native species can greatly reduce production cost. In Iran potential assessment of biodiesel production hasn't been studied yet. However, in the field of geothermal and wind power, production potential has been using GIS systems [7-9]. In this study, a GIS based approach is employed to investigate the biodiesel production potential based on native Tehran oil plants

\section{RESEARCH METHODOLOGY}

The sources of Iranian native plants have been investigated and native oil plants of Tehran province have been extracted to provide Tehran native oil plant statistics. Information related to the oil content of plants, vegetation and habitat conditions was 
obtained. Using climate and land use maps of Iran, the cultivation potential of these plants in all types of province surfaces is studied and finally, a map based on potential of producing biodiesel from native Tehran oil plants is presented. Tehran is located on the southern slopes of Alborz mountains, and in approximately equal distance from eastern (Afghanistan) and western (Turkey, Iraq) borders, sitting on the ancient and famous City of Rey. Tehran is not far from Khazar (Caspian Sea) with an aerial distance of 100 kilometers. On one hand it is situated on the route from Anatolia to India and China along Alborz Mountains and on the other hand, at the intersection of roads that extend from southern parts of the country along Zagros Mountains. Today, Tehran Metropolis is the most urbanized area between Istanbul and Karachi. These distinct elements have formed the region's landscape as well as its natural, social and cultural environment. Tehran is a mountainside city with an altitude of 900 to 1700 meters above sea level. Its urban area spreads entirely over the Iranian plateau, on the slopes of a very high and dense mountain barrier, with a peak of $3933 \mathrm{~m}$ which is $2200 \mathrm{~m}$ higher than the residential areas with rivers that are full in spring time and dry in summer time. In higher parts of the slope, it becomes cooler while major water resources in the area provide for the development of big and arborous villages. Lower parts, between 900 to $1200 \mathrm{~m}$, have a fertile soil and a gentle slope that permits a productive agricultural activity. In these plains, there are many sources of surface or underground water tables, supplied by aqueducts, flood ways and branched out rivers [10, 11]. In the southern part of Tehran and its suburbs, the desert begins. From geographic, natural and human points of view the same desert is the negative of the mountain side and has no significant role in Tehran's landscape and activities. The geographical situation of Tehran province and its cities are shown in Figures 1 and 2.

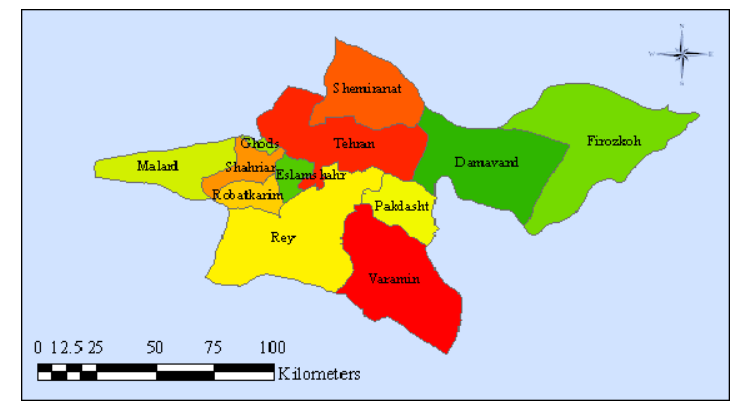

Fig. 1. Tehran province in Iran

The more factors involved in a feasibility study of biodiesel production, the more accurate the conclusion will be. Based on the available information and scientific resources of this area, some factors were selected as most important for determining appropriate zones in Tehran province to produce biodiesel. These factors included the type of climate, annual precipitation $(\mathrm{mm})$, temperature $\left({ }^{\circ} \mathrm{C}\right)$, soil texture and salinity. In this study, the digital maps have been prepared from Jamab Company research department and have been studied by geographic information systems (GIS). At the beginning, maps of Tehran province were extracted regarding rain, temperature and soil maps of Iran. Then, according to the model presented in Figure 3 , suitable areas for cultivation of the raw plant sources of biodiesel production in Tehran province were presented.

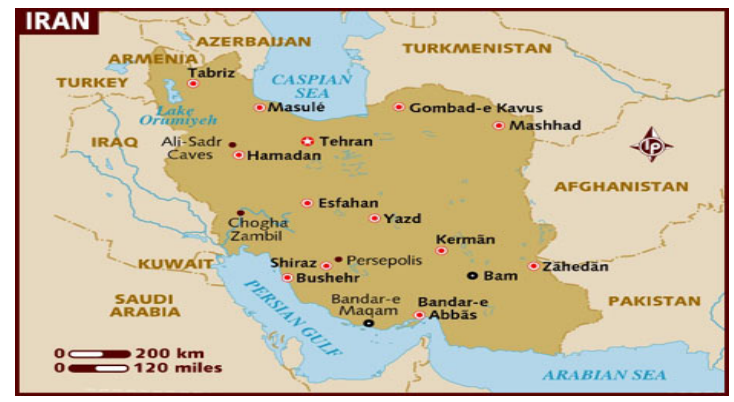

Fig. 2. The cities of Tehran province

\section{RESULTS AND DISCUSSION}

Annual rainfall and temperature, soil texture and soil salinity maps of Tehran province were prepared from Iran resource maps. Then, according to Table I these maps were classified separately in GIS. In Tehran province, average annual rainfall was classified from 150 to $800 \mathrm{~mm}$ per year by GIS. As can be seen in Figure 4, the highest average precipitation of $300 \mathrm{~mm}$ occurred in the central regions of the province. Rainfall levels in the northern part of Tehran located in the foothills of Alborz Mountain are above $500 \mathrm{~mm}$. Average annual temperature classified from minimum $5{ }^{\circ} \mathrm{C}$ to maximum $17.5^{\circ} \mathrm{C}$. Southern and south-western parts of the province with average temperatures of 12.5 degrees and above are more favorable for cultivating crops (Figure 5). Soil texture levels are classified to heavy, medium, light, rough and for non-agricultural land use. Medium level has the best soil texture for calculation which is concentrated in the western parts of the province (Figure 6). Soil salinity is categorized from low to extra salinity. Obviously, areas with less salinity are more suitable for production. As can be seen most of these areas are located in northern, eastern and some of them in western parts of the province (Figure 7).

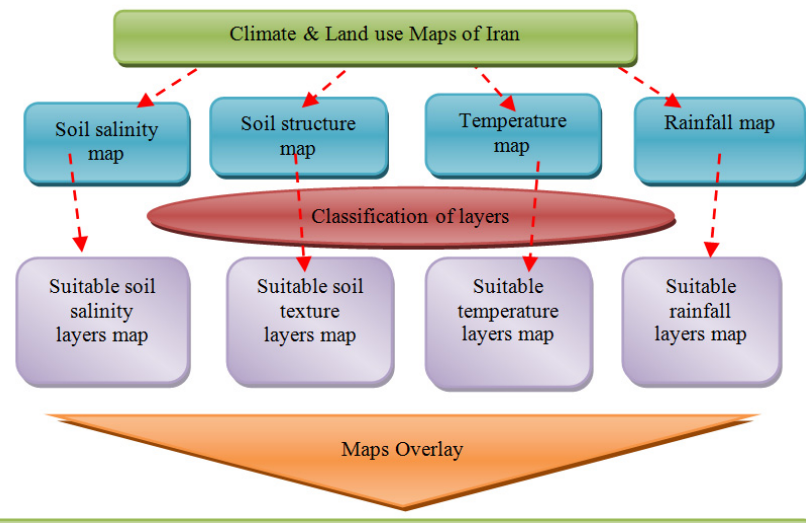

Tehran map for biodiesel production potential of indigenous oil crops resources

Fig. 3. GIS conceptual model used in this study. 
TABLE I. CLASSIFICATION OF MEASURES TO PRODUCE RAW MATERIALS FOR BIODIESEL PRODUCTION.

\begin{tabular}{|c|c|c|c|}
\hline Measures & Classes & $\begin{array}{l}\text { Classes } \\
\text { Range }\end{array}$ & Classes Name \\
\hline \multirow{5}{*}{$\begin{array}{c}\text { annual } \\
\text { rainfall } \\
(\mathrm{mm})\end{array}$} & 1 & $0-150$ & Inappropriate \\
\hline & 2 & $150-350$ & Relatively Poor \\
\hline & 3 & $350-550$ & Medium \\
\hline & 4 & $550-750$ & Modest \\
\hline & 5 & $750<$ & Appropriate \\
\hline \multirow{5}{*}{$\begin{array}{c}\text { annual } \\
\text { temperature } \\
\left({ }^{\circ} \mathrm{C}\right)\end{array}$} & 1 & $<10$ & Inappropriate \\
\hline & 2 & $10-12$ & Relatively Poor \\
\hline & 3 & $12-14$ & Medium \\
\hline & 4 & $14-16$ & Modest \\
\hline & 5 & 16-18 & Appropriate \\
\hline \multirow{5}{*}{ soil texture } & 1 & - & Heavy \\
\hline & 2 & - & Medium \\
\hline & 3 & - & Light \\
\hline & 4 & - & Macro \\
\hline & 5 & - & Land without Soil \\
\hline \multirow{5}{*}{ soil salinity } & 1 & - & Low \\
\hline & 2 & - & Medium \\
\hline & 3 & - & High \\
\hline & 4 & - & Quite a lot \\
\hline & 5 & - & Land without Soil \\
\hline
\end{tabular}

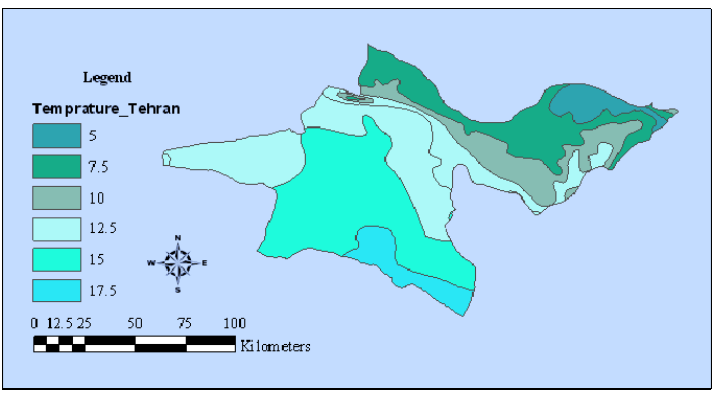

Fig. 4. Average annual precipitation levels

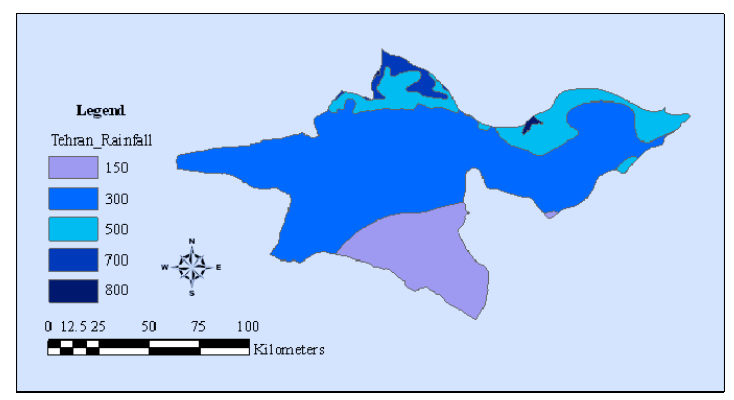

Fig. 5. Average annual temperature levels.

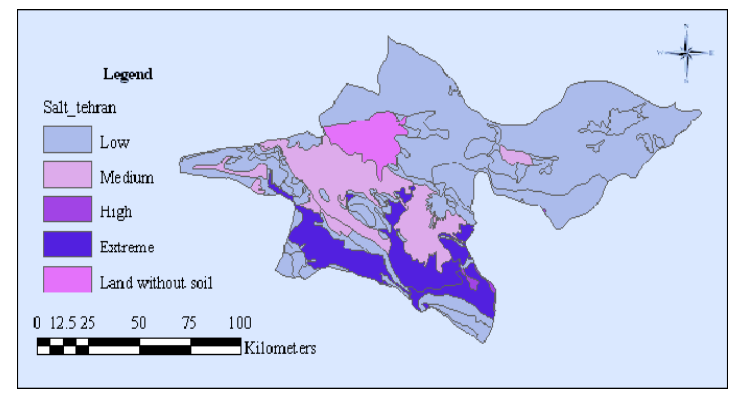

Fig. 6. Soil texture levels.

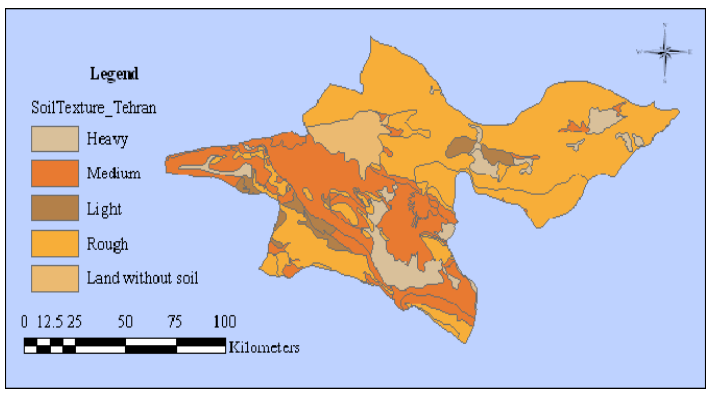

Fig. 7. Soil salinity levels

Some non-proliferation and dispersion endemic species have remained in the same small origin area. Tehran province has a diverse cover based on climate and other geographical conditions. Oil plants of Tehran are introduced in Table II. After identification of indigenous oil resource plants, levels of the products cultivation and their growth area were examined. Plants with low oil content (below 20\%oil content in seed or $10 \%$ in residue germ) or plants directly used as food and edible oil have been abandoned. In order to produce biodiesel, only three non-edible plants were looked upon: rapeseed, cotton and barley bran due to their compatible growing conditions with Tehran climate, high oil content, yield per hectare and not applicant as nuts or major edible. Non-edible rapeseed (Brassica carinata) is an oilseed crop with 30 to 50 percent oil content [12]. In this study, its industry variety was considered which isn't edible. Cotton (Gossypium Sp.) with 25 to 30 percent of oil content is among the oilseed crops [13]. The fiber of this plant is used for industrial production. Cotton oil seeds can be used to produce biodiesel.

Barley (Avena Sativa) is a kind of cereal that its shell and bran contains significant amounts of oil $(11 \%$ oil in residue germ) [14]. More cultivation of this plant in addition to increasing domestic production can provide large amounts of raw materials to produce biodiesel. Suitable areas for cultivation of these plants in province were looked for. Since the above mentioned plants need low water requirements, therefore, the average of annual rainfall of above $300 \mathrm{~mm}$ was selected as appropriate rain class (Figure 8). Base temperature for Canola, cotton and bully is respectively $5{ }^{\circ} \mathrm{C}, 12-15^{\circ} \mathrm{C}$ and $11^{\circ} \mathrm{C}$. Since the lowest temperature that all the three plants have the ability to grow is $12^{\circ} \mathrm{C}$ therefore classes with (12-14 $\left.{ }^{\circ} \mathrm{C}\right),\left(14-16{ }^{\circ} \mathrm{C}\right)$ and $\left(16-18{ }^{\circ} \mathrm{C}\right)$ were selected as the suitable temperature class (Figure 9). As mentioned earlier, the most suitable areas for cultivation are the ones with medium texture soil and low salinity. Thus, as shown in Table I, only class 2 of soil texture and class 1 of the soil salinity were selected as the suitable layers (Figures 10 and 11).

After provision of the favorable region maps to produce biodiesel raw material in Tehran province, four maps were obtained and overlaid and finally the feasibility map of producing biodiesel from oil plants in this province was presented (Figure 12). Considering the map, concentration of biodiesel production is in the central and western cities of province. Also this map shows that 116806.86 hectares of land have the greatest potential to produce biodiesel. 
TABLE II. OIL PLANTS OF TEHRAN PROVINCE.

\begin{tabular}{|c|c|c|c|c|}
\hline $\begin{array}{c}\text { Common } \\
\text { name }\end{array}$ & Scientific name & Family & $\begin{array}{c}\text { Oil } \\
\text { content }\end{array}$ & Oil organ \\
\hline Walnut & Juglans regia & Juglandaceae & 60 & seed \\
\hline Hazelnut & Corylus Colurna L. & Cupuliferae & 55 & seed \\
\hline Pistachio & Pistacia vera L. & Anacardiaceae & 54 & seed \\
\hline Sunflower & Heliantus annus & Compositae & 45 & seed \\
\hline Rapeseed & Brassica.napus.oleifera & Cruciferae & $30-54$ & seed \\
\hline Almond & Prunus communis & Rosaceae & 50 & seed \\
\hline Soybean & Glycin max & Fabaceae & 57 & seed \\
\hline Apricot & Prunus armeniaca & Rosaceae & $40-50$ & seed \\
\hline Prune & Prunus domestica & Rosaceae & 35 & seed \\
\hline Tomato & Solanum lycopersicum & Solanaceae & 35 & seed \\
\hline Cotton & Gossypium Sp. & Malvaceae & 20 & seed \\
\hline Chickpea & Cicer arietinum & Leguminoseae & 5 & seed \\
\hline Wheat & Triticum & Poaceae & 2 & germ \\
\hline Sea & Hippophae rhamnoides & Elaeagnaceae & $3-5$ & fruit \\
\cline { 3 - 5 } buckthorn & & & $8-18$ & seed \\
\hline Apple & Calocarpum mamossum & Rosaceae & $27.5-28$ & seed \\
\hline Grape & Vitis vinifera & Vitaceae & 12 & seed \\
\hline Oat & Avena Sativa & poaceae & 11 & bran \\
\hline
\end{tabular}

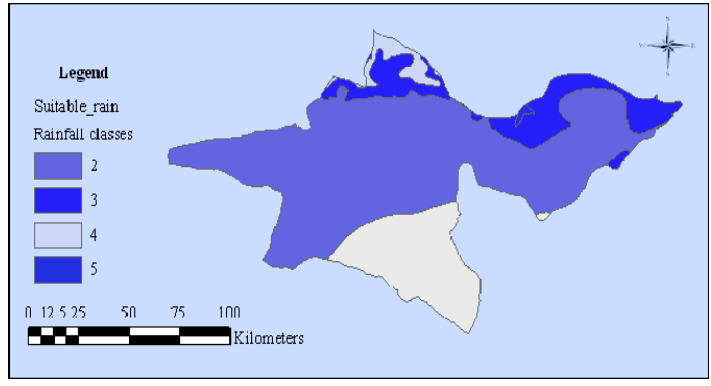

Fig. 8. Suitable class of precipitation.

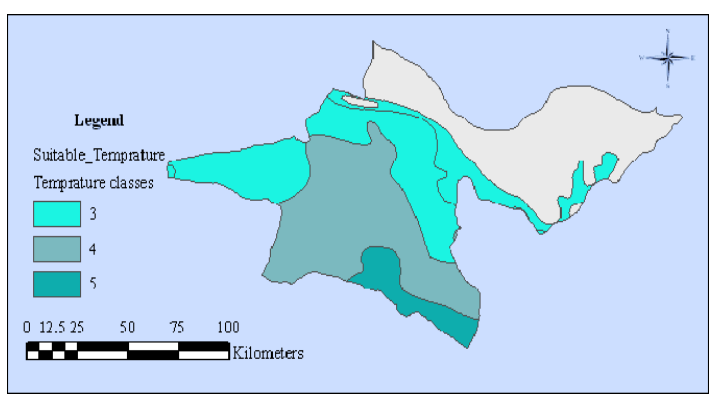

Fig. 9. Suitable class of temperature

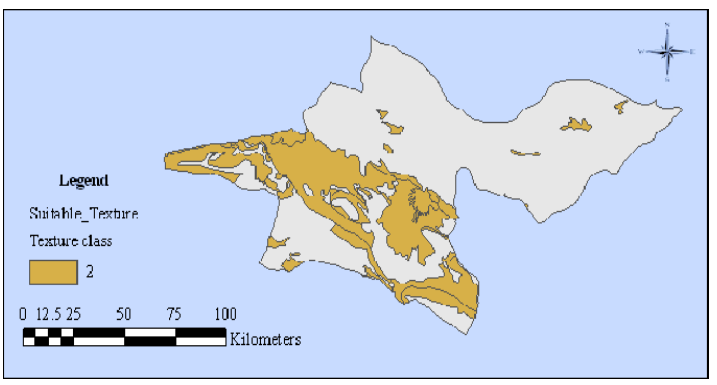

Fig. 10. Suitable class of soil texture

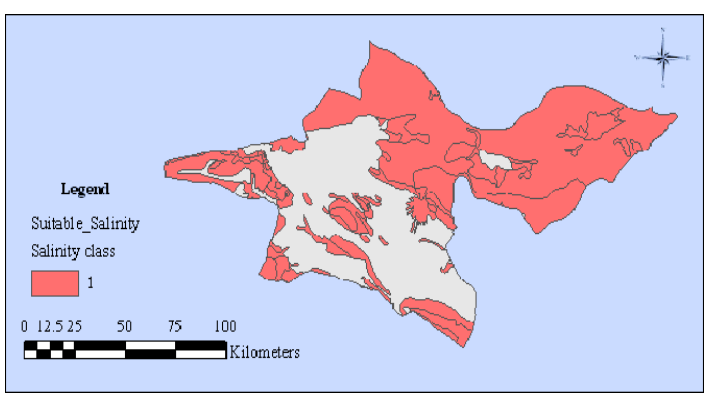

Fig. 11. Suitable class of soil salinity.

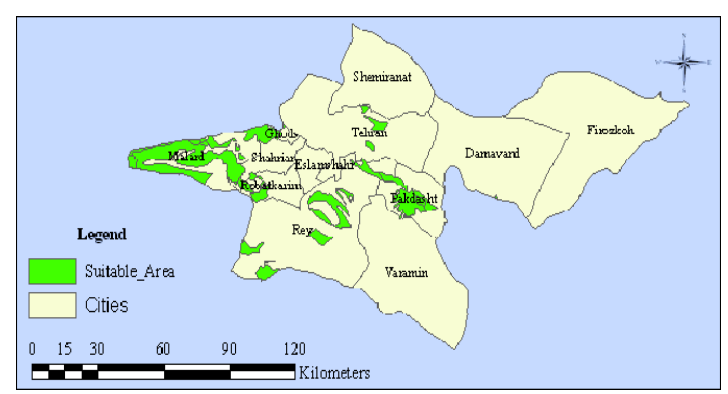

Fig. 12. Feasibility map of biodiesel production in Tehran

TABLE III. SUITABLE OIL PRODUCING PLANTS FOR TEHRAN PROVINCE

\begin{tabular}{|c|c|c|c|}
\hline Plant & Canola & Cotton & Barley \\
\hline Yield (tn/Ha) & 2.1 & 2.5 & 6.5 \\
\hline Oil contant (\%) & 40 & 20 & 11 \\
\hline $\begin{array}{c}\text { Biodiesel production } \\
\text { (tn/he) }\end{array}$ & 0.84 & 0.5 & 0.715 \\
\hline $\begin{array}{c}\text { Biodiesel production } \\
\text { In Tehran (ton) }\end{array}$ & 98117.77 & 58403.43 & 83516.91 \\
\hline
\end{tabular}




\section{CONCLUSION}

One of the main factors in the alternative fuel economy is feedstock. The importing of raw materials and the preparation conditions for the cultivation of non-native species require high expenditure. Therefore, using native species can greatly reduce biodiesel production cost. The purpose of this study is to propel relevant policies in Iran towards greater use of domestic raw materials and known potentials. The results of this study are as follows:

- This study was the first time that native oil plants of Tehran province and their oil content with suitable growth conditions was presented.

- Three non-edible species namely rapeseed, cotton and barley were selected due to their feasibility of producing biodiesel.

- After a survey of indigenous oil plant species of Tehran province, the potential for biodiesel production from plant sources, in this region has been studied using GIS software.

- The present paper describes the country zoning map and identifies the potential feasibility map of producing biodiesel from indigenous plant sources in Tehran province.

- Considering the selected map, concentrating of biodiesel potential production is in the central and western cities of province.

- The selected map shows 116806.86 hectares of land with the greatest potential to produce biodiesel.

- Potential of biodiesel production from introduced species, considering to the yield per hectare and their oil content, was calculated. The results show the potential of biodiesel production for the three species canola, cotton and barley are respectively $98117.77,58403.43,83516.91$ tons in Tehran province.

- Canola, with the highest production potential of 0.84 ton per hectare is introduced as a superior species for future investments in biodiesel production in Tehran province.

This map can also affect policy of the agricultural sector. Investing in the cultivation of biodiesel plants in these areas has the lowest risk of environmental damage and the highest efficiency potential especially if government support is directed towards biodiesel production.

\section{REFERENCES}

[1] D. Y. C. Leung, X. Wu, M. K. H. Leung, "A review on biodiesel production using catalyzed transesterification", Applied Energy, Volume 87, No. 4, pp. 1083- 1095, 2010

[2] E. J. Gauglitz Jr, L. W. Lehman, "The preparation of alkyl esters from highly unsaturated triglycerides", Journal of the American Oil Chemists Society, Vol. 40, No. 5, pp. 197-198, 1963

[3] Proceedings of the International Conference on Plant and Vegetable Oils as Fuels, North Dakota, American Society of Agricultural Engineers, 1982

[4] F. Maa, M. A. Hannab, "Biodiesel production. A review", Bioresource Technology, Vol. 70, No. 1, pp. 1-15, 1999
[5] M. Mittelbach, M. Worgetter, J. Pernkopf, H. Junek, "Diesel fuel derived from vegetable-oils: preparation and use of rape oil methylester", Energy in Agriculture, Vol.2, No. 4, pp 369 -384, 1983

[6] B. Ghobadian, TMU Research and Development Strategic Plan on Biomass and Bioenergy. Internal Report Prepared for Bioenergy Research Laboratory, Tarbiat Modares University, 2001

[7] H. Yousefi, Y. Noorollahi, S. Ehara, R. Itoi, A. Yousefi, Y. Fujimitsu, J. Nishijima, K. Sasaki, "Developing the geothermal resources map of Iran", Geothermics, Vol. 39, No. 2, pp. 140-151, 2010

[8] H. Yousefi, S. Ehara, Y. Nurollahi, "Geothermal potential site selection using GIS in Iran", 32nd Workshop on Geothermal Reservoir Engineering, pp. 174-182, 2007

[9] Y. Nurollahi, M. A. Ashraf, M Zamani, "Wind Power Potential Evaluation of Bakhtar Regionl using geographical information system (GIS)", Iran Energy Journal, Vol.14, No. 1, pp. 1- 21, 2011

[10] L. Khodapanah, W. N. A. Sulaiman, N. Khodapanah, N. "Groundwater Quality Assessment for Different Purposes in Eshtehard District, Tehran, Iran”, European Journal of Scientific Research, No.4, pp. 543-553, 2009

[11] L. Khodapanah, H. Jahanbin, M. Sabzevari, Annual Report of Groundwater Resources Exploitation, Deputy for Water Resources Study and Research, Tehran Regional Water Authority, 2005

[12] H. Myghany Mashhadi, Research on the use of rapeseed oil methyl ester as a fuel in a compression ignition engine with low round, $\mathrm{PhD}$ Thesis, University of Medical Sciences, Tehran, Iran, 2006

[13] D. K. Agarwal, P. Singh, M. Chakrabarty, A. J. Shaikh, S. G. Gayal, Cotton seed Oil Quality, Utilization and Processing, Central Institute for Cotton Research, Technical Bulletin No. 25, 2003

[14] N. T. Dunford, "Germ Oils from Different Sources", in: Bailey's Industrial Oil and Fat Products, Wiley, Vol. 6, 2005 